\title{
PROTOTYPE PENGENDALIAN DAYA LISTRIK AC DAN LAMPU DENGAN ANALISIS STANDAR KENYAMANAN RUANGAN BERBASIS ATMEGA 2560
}

\author{
Made Dwi Krisna Putra Sudiharta, I Gede Dyana Arjana, Cok Gede Indra Partha \\ Program Studi Teknik Elektro, Fakultas Teknik, Universitas Udayana \\ Email: krisnap30@gmail.com, dyanaarjana@unud.ac.id, cokindra@unud.ac.id
}

\begin{abstract}
Abstrak
Penggunaan AC dan lampu penerangan yang berlebihan dan tidak sesuai keperluan mengakibatkan kurangnya kenyamanan dan tingginya penggunaan energi listrik. Ultrasonik Sensor SRF-04 berfungsi mengetahui jumlah orang dalam ruangan, sensor suhu DHT 22 berfungsi menghitung suhu dan kelembaban dalam dan luar ruangan, Light Intensity sensor GY-302 berfungsi membaca tingkat intensitas cahaya dalam ruangan dan Mikrokontroler Arduino Mega 2560 berfungsi mem.proses masukan sensor-sensor menjadi perintah pengaturan pengoperasian unit AC dan lampu. Sistem pengontrolan AC dan lampu dapat bekerja dengan baik menentukan kapan dan jumlah AC dan lampu harus menyala, yang berpedoman pada standar kenyamanan ruangan masyarakat Indonesia sehingga dapat meningkatkan kenyamanan ruangan dalam hal sistem pendinginan dan pencahayaan ruangan dengan suhu $22^{\circ} \mathrm{C}$ hingga $25^{\circ} \mathrm{C}$ dan intensitas cahaya 300 lux.
\end{abstract}

Kata Kunci : Air Conditioner, Mikrokontroler Arduino Mega 2560, Thermal Comfort, Smart room

\begin{abstract}
The use of air conditioners (AC) and lighting that do not suit the needs and excessive results in a lack of comfort and high use of electrical energy. Ultrasonic Sensor of SRF-04 functions to find out the number of people in the room, temperature sensor of DHT 22 functions to calculate the temperature and humidity inside and outside the room, Light Intensity sensor of GY-302 functions to read the level of light intensity in the room and micro controller of Arduino Mega 2560 functions to process all input sensors become the command for operating the $A C$ units and lights. The $A C$ and lighting control system working well and can determine the time and number of $A C$ and light that is needed. Those are based by Indonesian room comfort standards so that it can increase the comfort of the room in terms of cooling systems and room lighting with a temperature of $22^{\circ} \mathrm{C}$ to $25^{\circ} \mathrm{C}$ and
\end{abstract} light intensity of 300 lux.

Keywords : Air Conditioner, Mikrokontroler Arduino Mega 2560, Thermal Comfort, Smart room

\section{PENDAHULUAN}

Sistem pengkondisi AC menggunakan energi listrik tidak sesuai dengan keperluan. Hasil audit energi menunjukan $60 \%$ pemakaian energi listrik digunakan oleh sistem pendingin ruangan $A C$ dari kapasitas energi yang dipasang [1]. Unit AC dan lampu yang beroperasi secara terus menerus tidak sebanding dengan kebutuhan BTUh (British Thermal Unit Per Hour) untuk AC dan Lux untuk penerangan di ruangan akan berdampak kepada suhu ruangan dan tingkat intensitas cahaya rendah ataupun tinggi sehingga menyebabkan kurangnya kenyamanan dan besarnya energi listrik yang digunakan.
Mikrokontroler dan sensor-sensor digunakan untuk mengatur pengoperasian AC dan lampu dengan otomatis di ruangan. Sensor digunakan adalah sensor dapat mengetahui keberadaan orang, suhu, kelembaban, dan intensitas cahaya ruangan. Ultrasonik sensor SRF-04 berfungsi mendeteksi keberadaan orang, sensor suhu DHT 22 berfungsi untuk mengukur suhu dan kelembaban, Light Intensity sensor GY-302 berfungsi untuk mengukur intensitas cahaya dan ATmega 2560 berfungsi untuk memproses masukan dari sensor menjadi perintah untuk mengatur pengoperasian unit $A C$ dan lampu di ruangan. Sistem pengontrolan $A C$ dan lampu harus dapat 
menentukan jumlah $\mathrm{AC}$ dan lampu harus menyala dengan cara mendeteksi dan menghitung jumlah orang di ruangan, menghitung suhu dan kelembaban ruangan yang berpedoman dari Thermal comfort yang dibutuhkan masyarakat Indonesia dan menghitung tingkat intensitas cahaya di dalam ruangan yang berpedoman pada tingkat lux yang dibutuhkan oleh ruangan.

Sistem yang dirancang diharapkan dapat meningkatkan efisiensi penggunaan energi listrik dengan memperhatikan unsur kenyamanan ruangan dalam hal sistem pendinginan dan pencahayaan ruangan.

\section{KAJIAN PUSTAKA}

\subsection{Air Conditioner}

Air Conditioner berfungsi untuk menstabilkan suhu dan kelembaban udara di ruangan ke suhu yang diinginkan menggunakan siklus refrigerasi. Proses pendinginkan ruangan $A C$ memiliki 3 bagian utama yaitu Kompresor, evaporator dan kondensor.

\subsubsection{Kompresor}

Kompresor berfungsi untuk mensirkulasikan dan menekan refrigan dalam sistem mesin pendingin. Akibat pendinginan di kondensor, refrigan bertekanan mencair dan secara bertahap melalui pipa kapiler atau katup expansi mengalir ke evaporator [2]. Gambar 1 menunjukan bentuk dari kompresor AC.

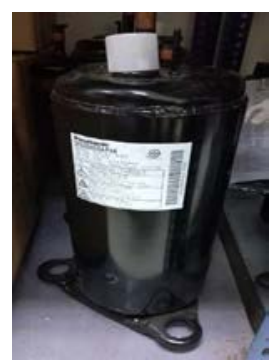

Gambar 1. Kompresor AC

\subsubsection{Evaporator}

Evaporator berfungsi mengubah sebagian atau keseluruhan sebuah pelarut dari sebuah larutan dari bentuk cair menjadi uap. Evaporator mempunyai dua prinsip dasar, untuk menukar panas dan untuk memisahkan uap yang terbentuk dari cairan [2]. Gambar 2 menunjukan bentuk dari evaporator AC.

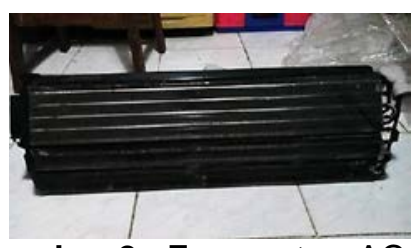

\subsubsection{Kondensor}

Gambar 2. Evaporatorr AC

Kondensor berfungsi untuk mengembunkan atau mengkondensasikan refrigeran bertekanan tinggi dari kompresor [2]. Gambar 3 menunjukan bentuk dari kondensor AC.

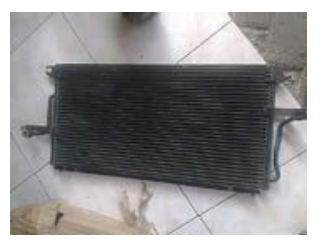

Gambar 3. Kondensor AC

\subsection{Standar Suhu Dan Kelembaban Ruangan}

Standar yang mengatur tentang tata cara perancangan sistem ventilasi dan pengkondisian udara. Daerah kenyamanan termal untuk daerah tropis dapat dibagi menjadi :

1. Sejuk nyaman, antara temperatur efektif $20,5^{\circ} \mathrm{C}$.

2. Nyaman optimal, antara temperatur efektif $22,8^{\circ} \mathrm{C} \sim 25,8^{\circ} \mathrm{C}$.

3. Hangat nyaman, antara temperatur efektif $25,8^{\circ} \mathrm{C} \sim 27,1^{\circ} \mathrm{C}$

Untuk ruangan yang jumlah orangnya padat, kelembaban udara relatif yang diperbolehkan berkisar antara 55\% $60 \%$. pengkondisian suhu ruangan diharapkan dapat memenuhi kondisi nyaman yaitu dengan suhu $22,8^{\circ} \mathrm{C}$ $25,8^{\circ} \mathrm{C}$ dan kelembapan relatif $55 \%$ $60 \%[3]$.

\subsection{Standar Pencahayaan Ruangan}

Keputusan Menteri Kesehatan No. 1405 tahun 2002, menyebutkan pencahayaan adalah jumlah penyinaran pada suatu bidang kerja yang diperlukan untuk melaksanakan kegiatan secara efektif [4]. Pencahayaan minimal yang dibutuhkan menurut jenis kegiatanya seperti ditunjukan Tabel 1. 
Tabel 1. Standar Tingkat Iluminasi Kepmenkes RI Tahun 2002

\begin{tabular}{|c|c|c|}
\hline $\begin{array}{c}\text { Jenis } \\
\text { Kegiatan }\end{array}$ & $\begin{array}{c}\text { Tingkat } \\
\text { Pencahayaan } \\
\text { Minimal }(\text { LUX) }\end{array}$ & Keterangan \\
\hline $\begin{array}{c}\text { Pekerjaan } \\
\text { Kasar dan } \\
\text { tidak terus } \\
\text { menerus }\end{array}$ & 100 & $\begin{array}{c}\text { Ruang } \\
\text { penyimpanan } \\
\text { dan pekerjaan } \\
\text { yang terus } \\
\text { menerus }\end{array}$ \\
\hline
\end{tabular}

Tabel 1. Standar Tingkat Iluminasi (Lanjutan)

\begin{tabular}{|c|c|l|}
\hline $\begin{array}{c}\text { Jenis } \\
\text { Kegiatan }\end{array}$ & $\begin{array}{c}\text { Tingkat } \\
\text { Pencahayaan } \\
\text { Minimal (LUX) }\end{array}$ & Keterangan \\
\hline $\begin{array}{c}\text { Pekerjaan } \\
\text { Kasar dan } \\
\text { terus } \\
\text { menerus }\end{array}$ & 200 & $\begin{array}{l}\text { Pekerjaan } \\
\text { dengan mesin } \\
\text { dan perakitan } \\
\text { kasar }\end{array}$ \\
\hline $\begin{array}{c}\text { Pekerjaan } \\
\text { rutin }\end{array}$ & 300 & $\begin{array}{l}\text { Ruang } \\
\text { administrasi, } \\
\text { ruang kontrol }\end{array}$ \\
\hline $\begin{array}{c}\text { Pekerjaan } \\
\text { agak halus }\end{array}$ & 500 & $\begin{array}{l}\text { Pembuatan } \\
\text { gambar atau } \\
\text { bekerja } \\
\text { dengan mesin } \\
\text { kantor dan } \\
\text { pemeriksaan }\end{array}$ \\
\hline $\begin{array}{c}\text { Pekerjaan } \\
\text { halus }\end{array}$ & 1000 & $\begin{array}{l}\text { Pemilihan } \\
\text { warna, } \\
\text { pekerjaan } \\
\text { mesin halus }\end{array}$ \\
\hline $\begin{array}{c}\text { Pekerjaan } \\
\text { amat halus }\end{array}$ & $\begin{array}{c}1500 \\
\text { Tidak } \\
\text { Menimbulkan } \\
\text { bayangan }\end{array}$ & $\begin{array}{l}\text { Perakitan } \\
\text { yang bersifat } \\
\text { halus }\end{array}$ \\
\hline $\begin{array}{c}\text { Pona } \\
\text { Tidak } \\
\text { terinci } \\
\text { bayimbulkan }\end{array}$ & $\begin{array}{l}\text { Pemeriksaan } \\
\text { pekerjaan } \\
\text { sangat halus }\end{array}$ \\
\hline
\end{tabular}

\subsection{Arduino Mega 2560}

Board Arduino Mega 2560 memiliki 54 buah digital pin input output (14 pin keluaran PWM), 16 pin analog input, 4 pin UART (serial port hardware). Arduino Mega 2560 dilengkapi dengan sebuah oscillator $16 \mathrm{Mhz}$, sebuah port USB, power jack DC, ICSP header, dan tombol reset [5]. Board Arduino Mega 2560 dapat dilihat pada Gambar 4.

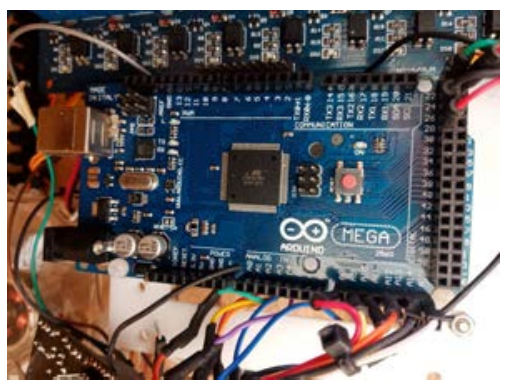

Gambar 4. Arduino Mega 2560

Arduino IDE (Integrated Development Environment) merupakan software bawaan dari Arduino yang digunakan dalam membuat listing program. Software Arduino IDE dapat melakukan proses compile dan upload program kedalam mikrokontroler Arduino [6].

\subsection{Sensor Ultrasonik HC-SR04}

Sensor Ultrasonik HC-SR04 menggunakan prinsip pantulan gelombang suara, digunakan untuk mendeteksi keberadaan objek di depannya. frekuensi kerja sensor ultrasonik berada pada 40 $\mathrm{KHz}$ hingga $400 \mathrm{KHz}$. Sensor ultrasonik terdiri dari dua bagian, yaitu unit pemancar dan unit penerima [7]. Sensor Ultrasonik HC-SR04 dapat dilihat pada Gambar 5.

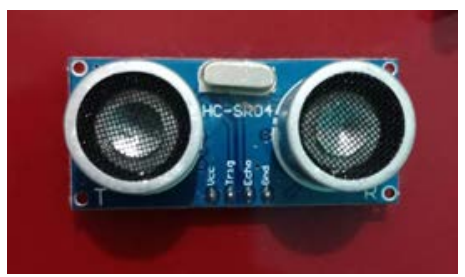

Gambar 5. Sensor Ultrasonik HC-SR04

\subsection{Sensor Suhu dan Kelembaban DHT-22}

Sensor DHT 22 digunakan untuk mengukur suhu dan kelembaban udara. Nilai Digital merupakan nilai Keluaran dari sensor suhu dan kelembaban DHT-22 sehingga analog digital converter (ADC) tidak diperlukan untuk mengakses keluaran sensor [8].

\section{METODOLOGI PENELITIAN \\ 3.1. Perancangan Prototype Secara Hardware}


Prototype menggunakan 2 buah sensor Ultrasonik SRF-04, 2 buah sensor suhu DHT 22 dan 1 buah sensor intensitas cahaya GY 302. Sensor Ultrasonik SRF-04 bertugas membaca keberadaan orang (human counter). Sensor suhu DHT 22 bertugas membaca suhu dan kelembaban luar dan dalam ruangan. Data yang didapatkan dari sensor-sensor diproses oleh Arduino Mega 2560 menggunakan analisis standar kenyamanan suhu dan penerangan ruangan untuk menentukan berapa jumlah AC dan lampu yang menyala menggunakan relay dan kontaktor. Diagram blok perangkat keras secara lengkap seperti ditunjukkan pada Gambar 6.

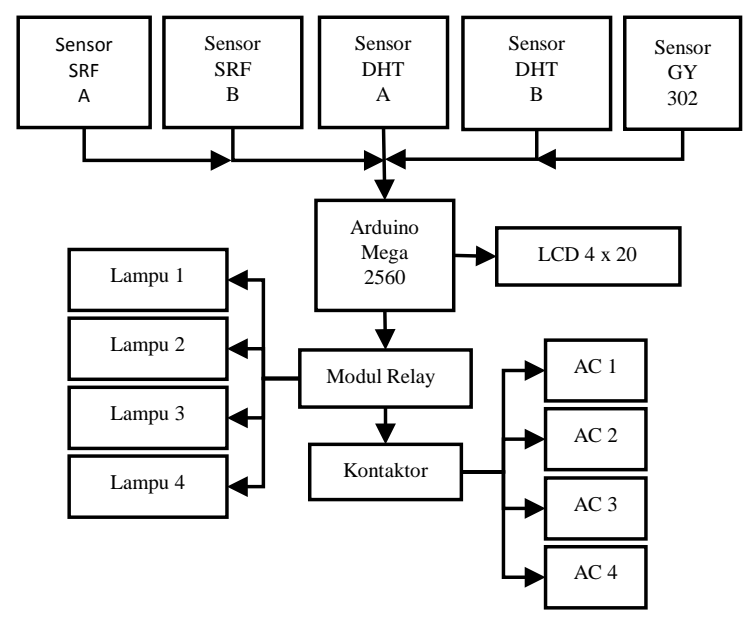

Gambar 6. Diagram blok hardware sistem prototype

Perangkat keras yang dirancang sebagai berikut :

1. Perancangan rangkaian sistem minimum Arduino Mega 2560.

2. Perancangan rangkaian sensor $\mathrm{UI}$ trasonik SRF-04

3. Perancangan rangkaian LCD.

4. Perancangan sistem rangkaian sensor suhu DHT 22

5. Perancangan rangkaian sensor intensitas GY - 302

6. Perancangan rangkaian Relay.

Setelah perancangan selesai, Dilanjutkan dengan realisasi rancangan, kemudian dilakukan pengujian pada masing masing bagian. Hasil perancangan ke- seluruhan komponen dapat dilihat pada Gambar 7.

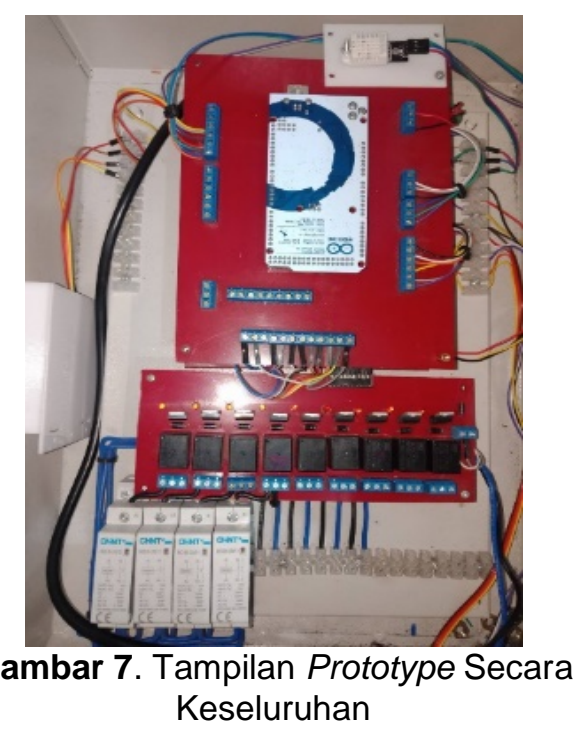

\subsection{Perancangan Prototype Secara Software}

\subsubsection{Diagram Alir Sistem Human Counter}

Prototype menggunakan 2 Sensor Ultrasonik HC-SRO4 untuk mendeteksi keberadaan orang. Ketika sensor ultrasonik A mendeteksi gerakan orang, maka nilai jumlah orang diruangan akan ditambah 1 , sebaliknya ketika sensor ultrasonik B mendeteksi gerakan orang maka jumlah orang diruangan akan dikurang 1. Gambar 8 menunjukan diagram alir proses human counting yang akan dibuat. 


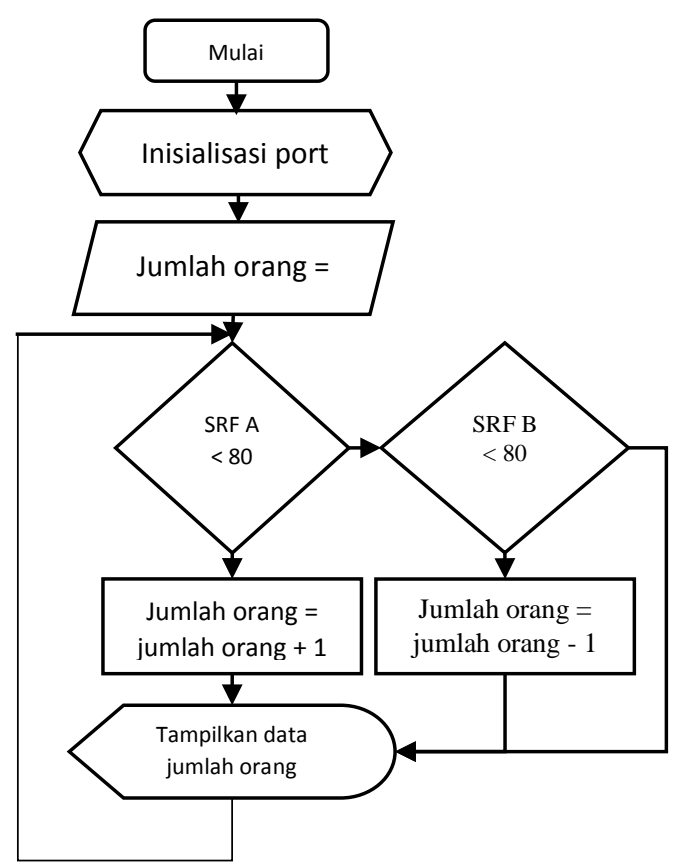

Gambar 8. Diagram Alir Kontrol Human Counter

\subsubsection{Perhitungan Kebutuhan AC Pada Ruangan DH 101}

Persamaan 1 digunakan untuk menghitung kebutuhan CLR (Cooling Load Ratio) pada ruangan $\mathrm{DH} 101$.

$C L R=P \times L \times T \times\left(\frac{\text { Kebutuhan } C L R}{m^{3}}\right)$

Diketahui :

$$
\begin{gathered}
\mathrm{P}=12 \mathrm{~m} ; \mathrm{L}=10 \mathrm{~m} ; \mathrm{T}=4 \mathrm{~m} \\
\left(\frac{\text { Kebutuhan } C L R}{\mathrm{~m}^{3}}\right)=150 \text { Btuh }
\end{gathered}
$$

Maka :

$$
\begin{aligned}
& C L R=12 \times 10 \times 4 \times\left(\frac{\text { Kebutuhan } C L R}{m^{3}}\right) \\
& C L R=480 \times\left(\frac{\text { Kebutuhan CLR }}{m^{3}}\right) . \\
& C L R=480 \times 150=72.000 \text { Btuh }=8 \mathrm{Pk} \\
& \text { Cooling load laki-laki dan wanita } \\
& \text { diasumsikan sama yaitu } 760 \text { Btuh, se- }
\end{aligned}
$$

Jumlah Orang Maksimal

$$
=\frac{72.000 \text { Btuh }}{760 \text { Btuh }}=94 \text { Orang }
$$

Jumlah Orang / 1 AC

$$
=\frac{94}{4}=230 \mathrm{rang}
$$

Tabel kerja ruang DH 101 ditunjukan oleh Tabel 2.

Tabel 2. Tabel Kerja AC Ruang DH 101

\begin{tabular}{|c|l|l|l|}
\hline No & Keterangan & $\begin{array}{c}\text { Jumlah } \\
\text { Orang }\end{array}$ & $\begin{array}{c}\text { AC } \\
\text { Aktif }\end{array}$ \\
\hline 1 & Sedikit & $1-23$ & 1 \\
\hline 2 & Sedang & $23-46$ & 2 \\
\hline 3 & Banyak & $47-69$ & 3 \\
\hline 4 & $\begin{array}{l}\text { Sangat } \\
\text { Banyak }\end{array}$ & $>69$ & 4 \\
\hline
\end{tabular}

\subsubsection{Kontrol AC Pada Ruang DH 101}

Suhu Luar ruangan sangat berpengaruh terhadap kenyamanan pendinginan ruangan, oleh karena itu dibutuhkan penambahan variabel suhu luar ruangan berdampak kepada penambahan jumlah AC yang dihidupkan saat awal. Suhu luar ruangan dikelompokan menjadi 4 kelompok yaitu : sejuk, hangat, panas, sangat panas. Sehingga dapat dibuat tabel penambahan jumlah AC yang dibutuhkan ditunjukan pada Tabel 3 .

Tabel 3. Tabel Pengaruh Suhu Luar Terhadap Kerja AC Ruang DH 101

\begin{tabular}{|c|c|c|l|}
\hline No & Keterangan & Suhu & $\begin{array}{c}\text { Penambahan } \\
\text { AC Aktif }\end{array}$ \\
\hline 1 & Sejuk & $<26^{\circ} \mathrm{C}$ & 0 \\
\hline 2 & Hangat & $\begin{array}{l}26^{\circ} \mathrm{C}- \\
29^{\circ} \mathrm{C}\end{array}$ & 1 \\
\hline 3 & Panas & $\begin{array}{l}30^{\circ} \mathrm{C}- \\
33^{\circ} \mathrm{C}\end{array}$ & 2 \\
\hline 4 & $\begin{array}{c}\text { Sangat } \\
\text { Panas }\end{array}$ & $>33^{\circ} \mathrm{C}$ & 3 \\
\hline
\end{tabular}

\subsubsection{Kontrol Lampu Pada Ruang DH 101}

Standar intensitas cahaya yang dibutuhkan dalam ruangan kelas adalah 300 Lux dari perhitungan yang telah dilakukan, maka dapat dibuat diagram alir pengontrolan lampu ditunjukan pada Gambar 9. 


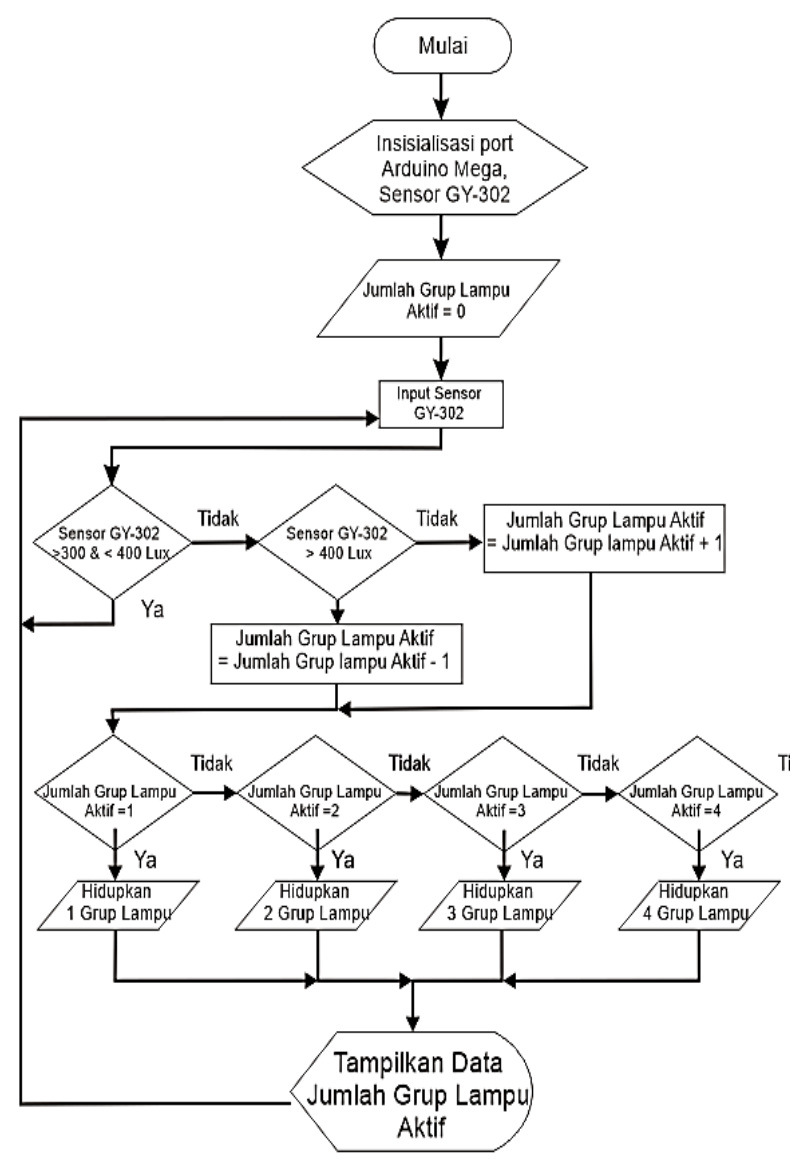

Gambar 9. Diagram Alir Kontrol Lampu Pada ruangan $\mathrm{DH} 101$

\section{HASIL DAN PEMBAHASAN}

\subsection{Pengujian Masing-Masing Komponen Penyusun}

Sistem kontrol yang sudah direalisasikan dilakukan pengujian, apabila hasil pengujian sudah memenuhui harapan maka dapat dilanjutkan dengan menggabungkan rangkaian yang ada sehingga sistem dapat memberikan hasil keluaran sesuai harapan.

\subsubsection{Pengujian Sensor Ultrasonik HC- SR04}

Pengujian dilakukan menggunakan media halangan dan alat ukur penggaris besi untuk mengatahui keakuratan pembacaan yang dilakukan sensor. Media halangan diletakan di hadapan sensor SRF A dan B sejauh $5 \mathrm{~cm}, 10 \mathrm{~cm}, 15 \mathrm{~cm}, 20$ $\mathrm{cm}, 25 \mathrm{~cm}, 30 \mathrm{~cm}, 35 \mathrm{~cm}, 40 \mathrm{~cm}, 50 \mathrm{~cm}$, $60 \mathrm{~cm}, 70 \mathrm{~cm}$ dan tanpa halangan, dengan hasil pengukuran ditunjukan oleh Gambar 10, 11, 12, 13 dan Tabel 4.

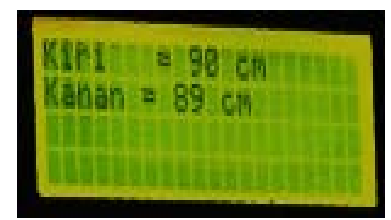

Gambar 10. Hasil Pengujian Sensor HC-SR04 tanpa halangan

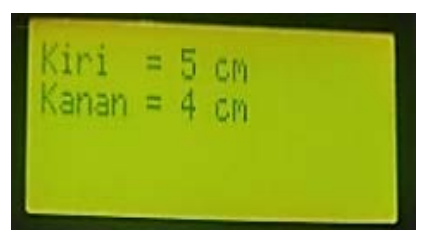

Gambar 11. Hasil Pengujian Sensor HC-SR04 dengan halangan $5 \mathrm{~cm}$

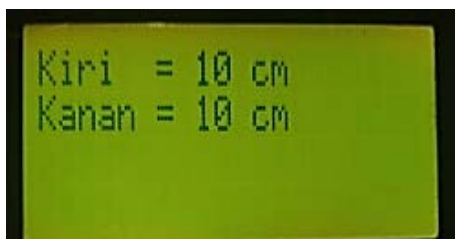

Gambar 12. Hasil Pengujian Sensor HC-SR04 Dengan halangan $10 \mathrm{~cm}$

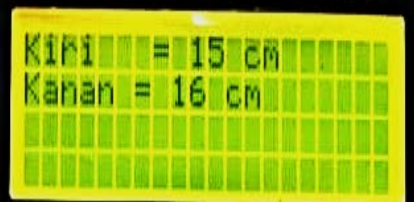

Gambar 13. Hasil Pengujian Sensor HC-SR04 Dengan halangan $15 \mathrm{~cm}$

Tabel 4. Hasil Pengujian Sensor HC-SR04

\begin{tabular}{|c|c|c|}
\hline Jarak Halangan & SRF A & SRF B \\
\hline Tanpa Halangan & $90 \mathrm{~cm}$ & $89 \mathrm{~cm}$ \\
\hline $5 \mathrm{~cm}$ & $5 \mathrm{~cm}$ & $4 \mathrm{~cm}$ \\
\hline $10 \mathrm{~cm}$ & $10 \mathrm{~cm}$ & $10 \mathrm{~cm}$ \\
\hline $15 \mathrm{~cm}$ & $15 \mathrm{~cm}$ & $16 \mathrm{~cm}$ \\
\hline $20 \mathrm{~cm}$ & $20 \mathrm{~cm}$ & $19 \mathrm{~cm}$ \\
\hline $25 \mathrm{~cm}$ & $25 \mathrm{~cm}$ & $25 \mathrm{~cm}$ \\
\hline $30 \mathrm{~cm}$ & $30 \mathrm{~cm}$ & $29 \mathrm{~cm}$ \\
\hline $35 \mathrm{~cm}$ & $35 \mathrm{~cm}$ & $35 \mathrm{~cm}$ \\
\hline $40 \mathrm{~cm}$ & $40 \mathrm{~cm}$ & $39 \mathrm{~cm}$ \\
\hline $50 \mathrm{~cm}$ & $50 \mathrm{~cm}$ & $50 \mathrm{~cm}$ \\
\hline $60 \mathrm{~cm}$ & $60 \mathrm{~cm}$ & $59 \mathrm{~cm}$ \\
\hline $70 \mathrm{~cm}$ & $70 \mathrm{~cm}$ & $70 \mathrm{~cm}$ \\
\hline
\end{tabular}

Hasil pembacaan sensor SRF A dan B tanpa media halangan adalah $90 \mathrm{~cm}$ dan $89 \mathrm{~cm}$ yang merupakan jarak terjauh pembacaan yang dibaca pada sensor, 
pada sistem merupakan kondisi tidak adanya orang yang melewati sensor. Hasil pembacaan sensor SRF memiliki perbedaan dengan jarak sebenarnya tidak terlalu mempengaruhi kinerja sistem karena yang diperlukan hanya kondisi ada tidaknya orang yang melewati sensor.

\subsubsection{Pengujian Sensor Suhu dan Kelembaban DHT 22}

Sensor diuji dengan cara menghubungkan dengan mikrokontroler kemudian membandingkan hasil pembacaan sensor dengan alat ukur suhu dan kelembaban. Hasil dari pengujian dapat dilihat pada Gambar 14 Tabel 4.3.

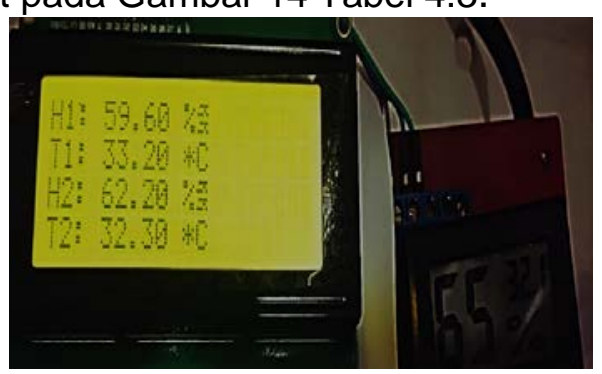

Gambar 14. Hasil Pengujian pembacaan suhu dan kelembaban sensor DHT A dan B.

Tabel 5. Hasil Pengujian Sensor DHT A dan B

\begin{tabular}{|l|l|l|l|l|l|}
\hline \multicolumn{5}{|c|}{ Hasil Pembacaan } \\
\hline \multicolumn{2}{|c|}{ Alat ukur } & \multicolumn{2}{|c|}{ DHT A } & \multicolumn{2}{c|}{ DHT B } \\
\hline Suhu & Kelembaban & Suhu & Kelembaban & Suhu & Kelembaban \\
\cline { 3 - 6 } & & Hasil & Hasil & Hasil & Hasil \\
\hline $\begin{array}{l}32,1 \\
{ }^{\circ} \mathrm{C}\end{array}$ & $65,0 \%$ & $\begin{array}{l}33,2 \\
{ }^{\circ} \mathrm{C}\end{array}$ & $59,6 \%$ & $32,3^{\circ} \mathrm{C}$ & $62,2 \%$ \\
\hline $\begin{array}{l}26,5 \\
{ }^{\circ} \mathrm{C}\end{array}$ & $70,0 \%$ & $\begin{array}{l}26,2 \\
{ }^{\circ} \mathrm{C}\end{array}$ & $65,4 \%$ & $25,4{ }^{\circ} \mathrm{C}$ & $67,4 \%$ \\
\hline $\begin{array}{l}20,1 \\
{ }^{\circ} \mathrm{C}\end{array}$ & $78,0 \%$ & 19,8 & $75,0 \%$ & $19,1^{\circ} \mathrm{C}$ & $74,0 \%$ \\
\hline $\begin{array}{l}18,2 \\
{ }^{\circ} \mathrm{C}\end{array}$ & $85,0 \%$ & $\begin{array}{l}{ }^{\circ} \mathrm{C} \\
18,1\end{array}$ & $85,1 \%$ & $18,1^{\circ} \mathrm{C}$ & $85,1 \%$ \\
\hline
\end{tabular}

Hasil pengujian sensor DHT A dan B mendapatkan hasil yang mendekati hasil pembacaan pada alat ukur suhu dan kelembaban.

\subsubsection{Pengujian Sensor Intensitas Cahaya GY-302}

Sensor diuji dengan membandingkan hasil pembacaan sensor dengan alat ukur lux meter. Gambar 15, 16 dan Tabel 6 merupakan hasil pengujian sensor GY-302.

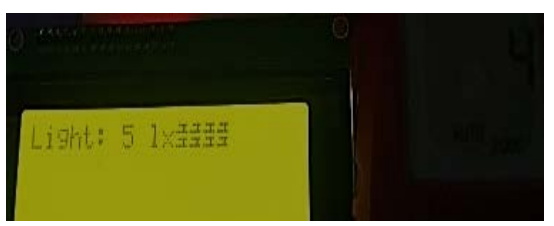

Gambar 15. Hasil Pengujian Sensor GY-302 saat gelap.

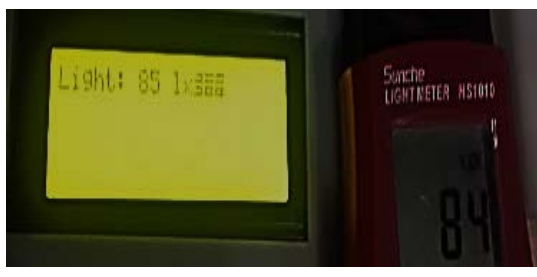

Gambar 16. Hasil Pengujian Sensor GY-302 saat terang.

Tabel 6. Hasil Pengujian Sensor GY-302

\begin{tabular}{|l|l|}
\hline $\begin{array}{c}\text { Alat Ukur } \\
\text { Lux Meter }\end{array}$ & \multicolumn{1}{|c|}{$\begin{array}{c}\text { Sensor } \\
\text { GY-302 }\end{array}$} \\
\hline 4 lux & 5 lux \\
\hline $84 \operatorname{lux}$ & 85 lux \\
\hline $290 \operatorname{lux}$ & 291 lux \\
\hline $368 \operatorname{lux}$ & $365 \operatorname{lux}$ \\
\hline $694 \operatorname{lux}$ & $682 \operatorname{lux}$ \\
\hline
\end{tabular}

\subsubsection{Pengujian Keseluruhan Sistem}

Pengujian dilakukan dengan cara melihat hasil keluaran pada prototype pengendalian daya listrik pada prototype air conditioner dan lampu penerangan dengan analisis standar kenyamanan ruangan berbasis Mikrokontroler Atmega 2560. Hasil pengujian keseluruhan ditunjukan oleh Gambar 17.

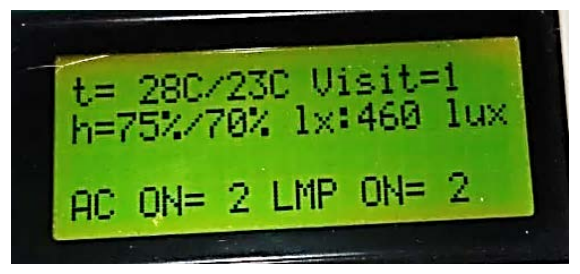

Gambar 17. Hasil Pengujian Keseluruhan Sistem.

Hasil pengujian dari prototype yang di jabarkan sebagai berikut :

1. kondisi 1 saat tidak ada orang di ruangan, lampu dan AC tidak menyala. 
2. kondisi 2 saat ada orang yang memasuki ruangan, AC dan lampu pada ruangan menyala sesuai dengan pengaturan jumlah $A C$ dan lampu. Jumlah AC menyala pada kondisi 2 bergantung pada suhu luar ruangan, semakin tinggi suhu luar ruangan maka semakin banyak pula AC menyala.

3. Kondisi 2 hingga kondisi 4 lampu menyala pada ruangan jumlahnya terus meningkat menyesuaikan nilai intensitas cahaya di ruangan hingga bernilai 300-400 lux yang merupakan standar pencahayaan pada ruangan kelas.

4. Kondisi 5 menunjukan hasil pengaturan suhu ruangan sesuai dengan standar kenyamanan ruangan yaitu berada pada suhu $22^{\circ} \mathrm{C}-25^{\circ} \mathrm{C}$.

5. Kondisi 6 menunjukan adanya peningkatan intensitas cahaya di ruangan mencapai 460 lux, sistem langsung melakukan proses dengan mengurangi jumlah lampu pada ruangan hingga tercapai standar pencahayaan pada ruangan.

6. Kondisi 10 menunjukan penurunan suhu ruangan menjadi $21{ }^{\circ} \mathrm{C}$ sehingga kurang dari standar, apabila dalam 10 menit suhu tidak berada pada kondisi standar, jumlah AC menyala di ruangan akan dikurangi 1 yang ditunjukan pada kondisi 12.

7. Kondisi $\mathbf{1 3}$ menunjukan suhu di ruangan sudah kembali pada kondisi standar suhu ruangan.

8. Kondisi 14 menunjukan peningkatan jumlah orang di ruangan hingga 25 orang, jumlah AC menyala di ruangan ditambah 1 unit.

9. Kondisi 15 menunjukan kenaikan suhu ruangan mencapai $26{ }^{\circ} \mathrm{C}$ akibat penambahan jumlah orang di ruangan, apabila dalam 10 menit suhu di ruangan tidak juga kembali ke kondisi standar, sistem akan mulai menambah jumlah AC yang menyala di ruangan.

10. Kondisi 18 menunjukan adanya penambahan jumlah orang di ruangan mencapai 50 orang, sehingga jumlah
AC yang menyala di ruangan bertambah menjadi 4 unit.

\section{KESIMPULAN}

Hasil dari pembahasan yang telah diuraikan dapat disimpulkan :

1. Sistem prototype sudah dapat menghitung naik (counter Up) ketika sensor SRF $A$ dilewati orang dan menghitung turun (counter down) ketika sensor SRF B dilewati orang.

2. AC dan lampu di dalam ruangan, sudah menyala apabila jumlah orang di ruangan berjumlah 1 orang dan padam apabila tidak ada orang di dalam ruangan.

3. AC yang menyala pada ruangan jumlahnya bergantung pada suhu luar ruangan, suhu dalam ruangan dan jumlah orang dalam ruangan yang berpedoman pada standar kenyamanan suhu ruangan yaitu $22^{\circ} \mathrm{C}$ hingga $25^{\circ} \mathrm{C}$.

\section{DAFTAR PUSTAKA}

[1] Abdul Malik, "Audit Energi Pada Gedung IV Kantor PT PLN (PERSERO) Wilayah Kalimantan Barat," PT PT PLN Persero Wil. Kalimantan Barat, hlm. 1-3, 2013.

[2] Darwis Tampubolon dan Robert Samosir, "Pemahaman Tentang Refrigrasi.," Politek. Negeri Medan, hlm. 4-9, 2005.

[3] [3] Standar Nasional Indonesia, "Tata cara perancangan sistem ventilasi dan pengkondisian udara pada bangunan gedung, Badan Standarisasi Nasional," vol. 03-6572-2001., 2001.

[4] Kementrian Kesehatan Republik Indonesia, "Persyaratan Kesehatan Lingkungan Kerja Perkantoran Dan Industri, Tata Kelola Pencahayaan," 2002.

[5] "Arduino Mega 2560," Arduino. .

[6] "Arduino software," Arduino. . 
[7] "SR04 Ultrasonic Module User Guide," Ultrasonic Sensor HC-SR 04. .

[8] "Sensor DHT22," Temperature Sensor DHT22. . 